\title{
Computer Based Support for Mathematics Education in Serbia
}

\author{
Jovana Jezdimirović \\ Faculty of Mathematics, University of Belgrade
}

\begin{abstract}
The aim of this paper is to present public $e$ course and advantages of using digital tools (techniques) for visualization and interactive approach in mathematics education at undergraduate university level. This material consists e-lessons of the Differential Calculus created within software package GeoGebra and following topics are included: functions of a real variable, arrays, limit function, continuity of functions, derivatives, applications of derivatives and interrelationships between theory and its applications in sciences. Integral parts of each elesson are dynamic geometric constructions made by GeoGebra applets, very strong theoretical background and traditional calculus tools. The aims of created didactic e-material are to encourage students to make connections between visual and symbolic representations of the same mathematical notions and to let them explore links between parameters, graphs and their application in tasks, sciences and everyday life. Designed teaching and learning material, e-Differential Calculus, meets and fosters individual learning styles, interest and capabilities, which make it suitable and for inclusive and lifelong learning. Left to be discovered is how are the imagery, interactivity, motivational and selfregulated learning components related to student performance on academic tasks and cognitive issues.
\end{abstract}

\section{Introduction}

The main indicator of development of any society is its concern and contribution to education of each individual. Therefore, it is essential for educational system in general to create teaching/learning environment which suit to all involved in the process. On the other hand, it is very difficult and at the same time essential to establish all relevant criteria and develop teaching both learning ematerials which meet the same basic pedagogical, psychological and methodological issues, with special attention to curricula and students needs and interests. Modern society has found contemporary methods and methodologies to overcome these problems in a way of creating new media for expansion of knowledge involving technology and Internet in education process.

When it comes to importance of developing and applying conceptual knowledge, an important place is devoted to the Internet platform aimed Problem Based Learning in ICT with a significant impact of a wide range of options of materials available to educators as in [1]. Also, there is a growing number of educators who devote a significant role in teaching approaches of Blended Learning (BL), which is a combination of Computer Supported Collaborative Learning (CSCL), Problem Based Learning in ICT (PBL) and traditional methods of learning according to [2]. Even when it comes to estimating students achievement BL occupies an important place as reported in [3] and provides variety of other crucial benefits for education process in general according to [4]. At the same time, Mobile Learning (ML) is developing rapidly and an increasing number of applications intended for specific teaching content has been designed with highly successful examples of implementation in practice as in [5]. On the other hand, the authors as Frohberg, Goth and Schwabe in [6] argue that there is no clear methodology that would apply the usage of this kind of materials in education process in general, which emphasizes the need for detailed pedagogical caution in creating didactic e-materials.

The influence of technology, particularly in dynamic computer environments, was explored and continues to be a significant focus as well as gender differences in use of mathematical visualization, and mathematicians' uses of imagery.

Widening effects of computer technology in mathematical visualization prove that this methodology have affective attributes in systems of representation in mathematical problem solving processes. This teaching both learning approach represents powerful engine not only in mathematical topics such as geometry and trigonometry but also in algebra, analyses, etc. There have also been reported many special advantages of computer software usage that encourages dynamic visualization according to [7]. Dynamic geometry systems (DGS) like Cabri or 
Cinderella and computer algebra systems (CAS) such as Maple, Derive or Mathematica have greatly influenced mathematics education and these powerful tools have been totally unconnected, though. GeoGebra is a new software system that integrates possibilities of both dynamic geometry and computer algebra in one tool for mathematics education, as reported in [8]. GeoGebra fulfills all educational functions of new media and represents a cooperation-, communication- and representation tool suitable for strengthening math knowledge both visualizing variety of abstract concepts.

On the other hand, it is clearly that visualization can't be used as 'panacea' for each math classroom situation since an intuition about a generalization involves more than observed evidence. For example, although one calculus images supported his level of mathematical functioning, occasionally his vivid images became uncontrollable and the power of these images did more to obscure then to explain. This type of imagery can be a major hindrance in constructing meaning for mathematical concepts. Some of the reasons are: the belief that visual proof is not 'real' mathematical proof, the algebraic mode instead of the graphic or visual is more commonly used when solving routine problems on calculus tests and the belief held by students and teachers that doing calculus is skillfully manipulating numbers and symbols, according to [9].

In order to assess all relevant indicators of good educating practice, it is crucial to evidence the importance both motivational and self-regulated learning components in our models of classroom academic performance. Student involvement in selfregulated learning is closely tied to student's efficacy beliefs about their capability to perform classroom tasks and their beliefs that these classroom tasks are interesting and worth learning. At the same time, these motivational beliefs are not sufficient for successful academic performance; self-regulated learning components seem to be more directly implicated in performance, other words students need to have both the "will" and the "skill" to be successful in classrooms and it is educator's duty to integrate these components in their models of classroom learning according to [10].

\section{E-learning in Serbia}

Educational system in general has been coping with challenging issue of integration dichotomy since technology got involved.

There are many pros. and cons. for both traditional training and e-learning approach and the question if it's online vs. face-to-face instruction or not still remains. Nowadays, most of educators choose a solution that would satisfy both sides: blended learning: classroom-online-mobile approach. Advantages of e-Learning are accessibility and availability of educational materials, especially considering Massive Open Online Courses (MOOCs). At the same time, e-Teaching has enabled cheaper studying costs, working and studying, no visa problems for students, advertisement for institution, etc.

On the other hand, educational system in Serbia has adopted traditional training as the only and the most convenient approach for students at all levels. Some of possible causes for this particular kind of training are: the lack of tutor practice in ICT integration, technical support and examples of good e-teaching approach. Reasons as poor awareness of advantages of e-education and deficiency in available e-materials in Serbian language and appropriate educational software certainly cannot increase the chances of changing present situation. As a matter of fact, there are only few courses and interactive educational materials which can help students in Serbia to adjust learning with their own interests and accomplishments.

Integration of ICT in teaching is reflected only in the implementation of the lecture slides with poor interactivity i.e. usage of Power Point Presentations. Serbian educators don't know who could help them with the issue of innovation and integration of ICT in their classroom performance, although they have a strong desire to modernize their lessons, according to the results of the national research which integrated one hundred primary schools teachers of all subjects with various level of the professional experience, as reported in [11].

In order to improve mathematics teaching, professional development of educators and integration of ICT in classroom environment, members of a non-profit educational organization GeoGebra Center Belgrade (GGB C BG) as an integral part of Faculty of Mathematics, University of Belgrade, Serbia, for the past couple of years have been creating interactive e-materials, lecturing accredited seminars, giving training and workshops for the educators of all levels. Numerous educational e-materials and web platforms have been created for all levels of mathematical education as in Table 1.

Table 1. Available e-materials for mathematics education in Serbian language, designed by GeoGebra Center Belgrade

\begin{tabular}{lc}
\hline Level & $\begin{array}{l}\text { Number of didactic } \\
\text { e-materials }\end{array}$ \\
\hline Kindergarten & low \\
\hline Primary school & satisfying \\
\hline
\end{tabular}




\begin{tabular}{ll}
\hline & \\
\hline High school & large-scale \\
\hline Undergraduate level & large-scale \\
\hline $\begin{array}{l}\text { Applications } \\
\text { of mathematics }\end{array}$ & large-scale \\
\hline
\end{tabular}

The aims of these materials are not only to help students with learning, homework assignments, to prepare them for national final exams but also and to reinforce their motivation, knowledge and skills that will be useful in their future academic performance.

At the same time, members of GGB C BG tried to help teachers as well, in providing support in monitoring student's progress after each lesson, analyze data and adapt teaching to student's needs and interests. When it comes to younger pupils, special web platform is created to include parents in educational process as well, in order to discover and help individual achievements and motivation problems of each student not only on classrooms', but also and on homework assignments' basis.

Members of the GGB C BG, among whom I am, are providing publicly available modern teaching materials for mathematics, examples of interactive GeoGebra applets, instructions for creating dynamic web pages that can be used in the teaching of mathematics as well as counseling and sharing ideas on organizing innovative and multimedia lessons.

Currently monitoring of impacts and potentials of created interactive didactic e-materials for mathematics education through a variety of studies should provide answers to all relevant questions about the effects of their implementation in the education process as well as contribution to motivation and students achievements.

\section{E-Differential Calculus}

Differential calculus is the field of mathematical analysis which deals with the study and application of derivatives, and whose roots reach to the $17^{\text {th }}$ century and the time of Newton and Leibniz. Applications of differential calculus over time grew exponentially, so the new theory intrigued many scientists and mathematicians such as Euler, Riemann, Fourier, Abel, etc. which eventually caused this mathematical theory further developed and popularized. By the beginning of the $21^{\text {st }}$ century, many physical manifestations have been explained using this new mathematical tool. Numerous differential calculus models have proved to be useful in: physics, chemistry, medicine, mechanics, electrical engineering, finance, and many other sciences, which testify the importance of the mentioned theory. This paper has attempted to explain various mathematical concepts from differential calculus in a new way, which is understandable and closer to students interests, as well as to highlight its applications in science. It is designed as a didactic resource that will make teaching more productive and more interactive and, with great hope, learning more challenging and interesting.

The developed material visualizes crucial mathematical concepts of the Differential Calculus curriculum and allows students to explore outline links between them. It was primarily created for undergraduate students, but the animations' adjustments and a great number of interactive explanations make it suitable and for the younger pupils, as well as for the purposes of lifelong learning. Some of the advantages of designed ecourse are that: physical representation of theorems, visualization of abstract concepts, numerous examples in the context of everyday life, interactive proofs of the theorems, geometrical representations of mathematical concepts, etc. have been presented.

E-course is consisted of e-lessons which are in accordance to curriculum as in Table 2. Each lesson supports basic differential calculus tools as notation, graphs, theorems and proofs with additional interactive representation of each abstract concept.

Table 2. e-Course of Differential Calculus

\begin{tabular}{llc}
\hline \multicolumn{1}{c}{ Contents } & $\begin{array}{c}\text { Number of } \\
\text { lessons }\end{array}$ & Animations \\
\hline Functions & large-scale & frequent \\
\hline Arrays & large-scale & frequent \\
\hline $\begin{array}{l}\text { Limit } \\
\text { function }\end{array}$ & large-scale & frequent \\
\hline $\begin{array}{l}\text { Continuous } \\
\text { Functions }\end{array}$ & large-scale & frequent \\
\hline $\begin{array}{l}\text { Differential } \\
\text { large-scale }\end{array}$ & frequent \\
\hline $\begin{array}{l}\text { Applications } \\
\text { of differentials }\end{array}$ & large-scale & frequent \\
\hline
\end{tabular}

E-material is focused specifically on improving teaching materials and emphasizes the "interactivity". Each animation is created with GeoGebra software and is interactive so students can change the position of the various parameters and use the interactive buttons Start, Stop, Refresh, etc. It is also recommended that students work individually or in pairs/groups, in the package software GeoGebra, in order to create their own 
applets and learn by trying and constructing (which functions are differentiable, changing the function graph, etc.). This activity will make them able to correlate between different mathematical fields (algebra, geometry, analysis) because of the advantages of GeoGebra software and to find interconnections of mathematics to other sciences (physics, chemistry, etc.) by making their own GeoGebra applets and designs.

At the same time, the aim of this e-course is also to present "applicability" of mathematical concepts in everyday life and learning beyond the classroom. All of created applets visualizes and simplifies presented mathematical concepts in order to develop adequate background for tackling real-world problems and innovative learners as well.

The Differential Calculus is a crucial tool used not only in mathematics, but in many other sciences. Therefore it is essential for students to develop the idea of a derivation concept. By making interactive materials for this topic within GeoGebra applets, the aim is to let students work with interactive animations and improve their skills for estimating predicting. For example: applets for basic function graphs are created with the idea of understanding graph changing depending on parameters as in Figure 1. and Figure 2.

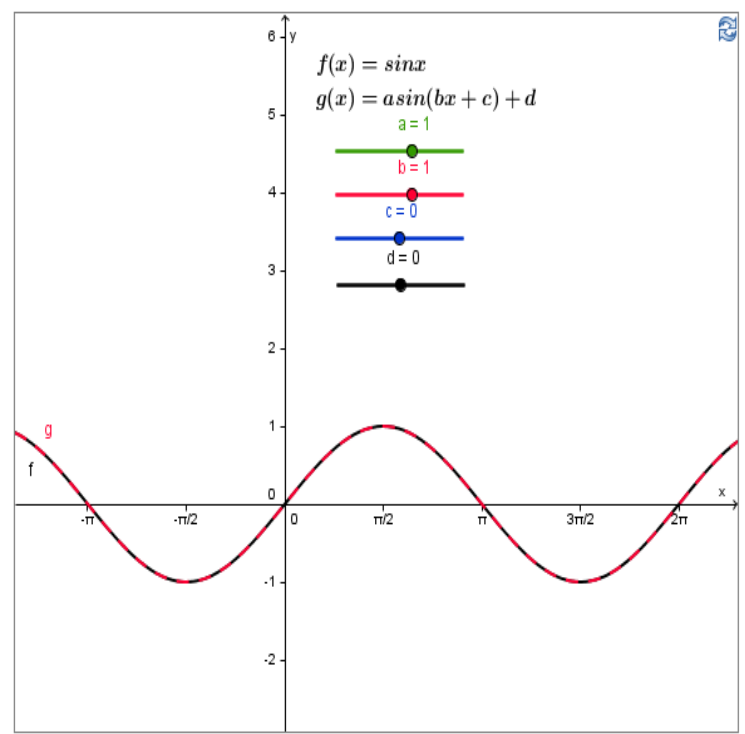

Figure 1. Function graph $f(x)=a \sin (b x+c)+d$

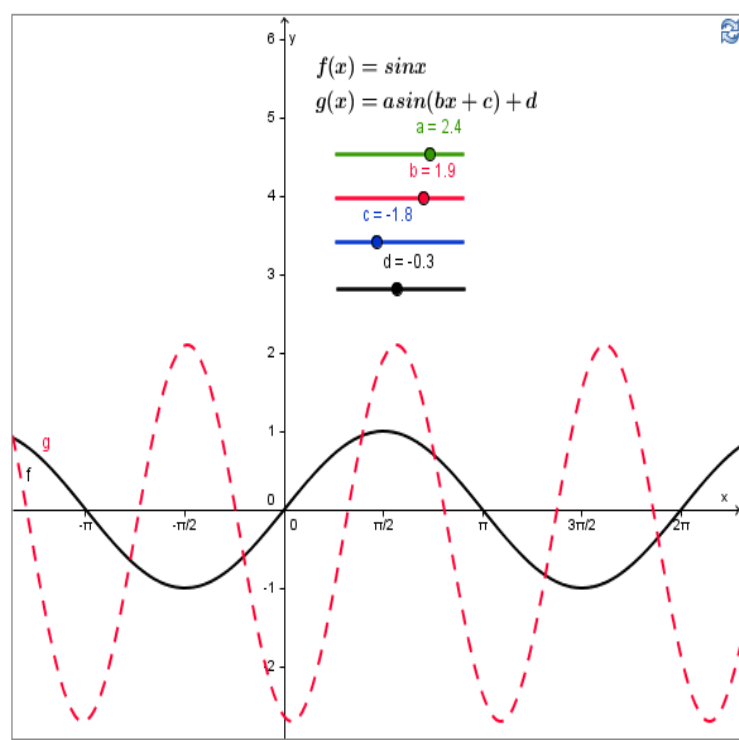

Figure 2. Function graph $f(x)=a \sin (b x+c)+d$

One of the goals of the e-course is not only to introduce students with the most common geometrical representation of the derivative (investigating the slope of a secant as in Figure 3.), but also to discover, understand and explore scientific "time derivative" idea (as in Figure 5.) which is very common when it comes to mathematical modeling in science (velocity, acceleration, oscillations, damped oscillations, etc).

E-material highlights the student's need to discover and explore correlations between real situation problems and mathematical models through idealization and mathematization processes. Students are encouraged to use different tools and techniques to reveal interrelationships among various types of mathematical problems and its applications.

Designed e-material of Differential Calculus also supports the needs of modern students to learn with computers, not only how to use computers. At the same time e-course is focused on using traditional literature as $[12,13,14,15,16,17,18]$ in order to foster student's qualitative knowledge of this mathematical area. Its global availability on http://alas.matf.bg.ac.rs/ ml08060/ makes it easily accessible 24 hours a day, 7 days a week for educators both learners, with only requirement of java software.

The visual process which follows more comprehensive and generalized mathematical knowledge is encouraged and enhanced by the dynamic software GeoGebra. Advantages of being able to move flexibly amongst multiple registers and the benefit of visual depiction which clearly manifests the difference between various types of mathematical problems are powerfully illustrated in [7]. 


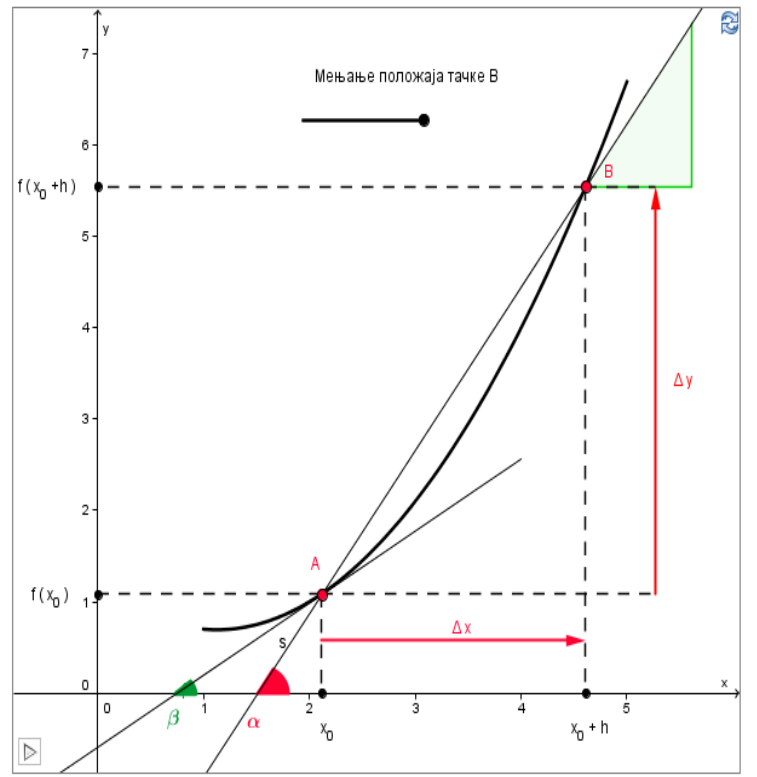

Figure 3. Geometric representation of the differential

As a way of overcoming the anxiety of reading, learning and understanding mathematical literature that includes theorems and proofs, the e-material offers numerous animation of these and similar problem-solving concepts in mathematics.

Physically-geometrical representation of Taylor's polynomial and Rolle's as well as the Lagrange's mean value theorems are, among all, also presented. In the Figure 5. is shown mechanical animation of Rolle's theorem which explains the theorem and its proof using interactive GeoGebra applet.

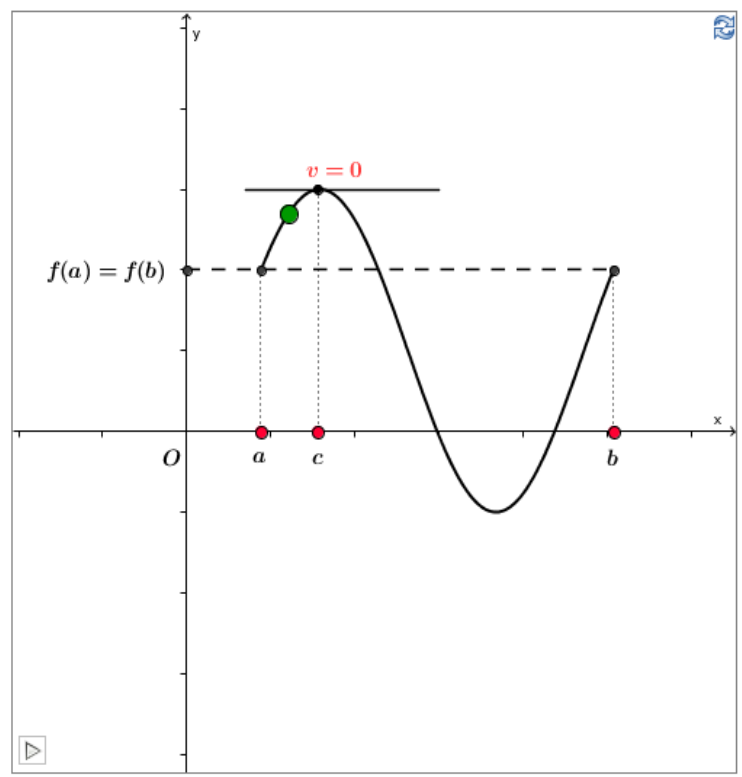

Figure 4. Physical representation of Rolle's mean value theorem
In appendix of the e-material are scientific important animations of functions (cardioid function, astroid function, etc) and different interactive models used in science and everyday life (bisection method, mathematical model of an earthquake problem used in civil engineering in Figure 5.) relying on [18, 19]. This teaching/learning approach is specially designed to promote the ability to apply mathematics to realworld problems and at the same time to develop a balanced image of mathematics as a science.

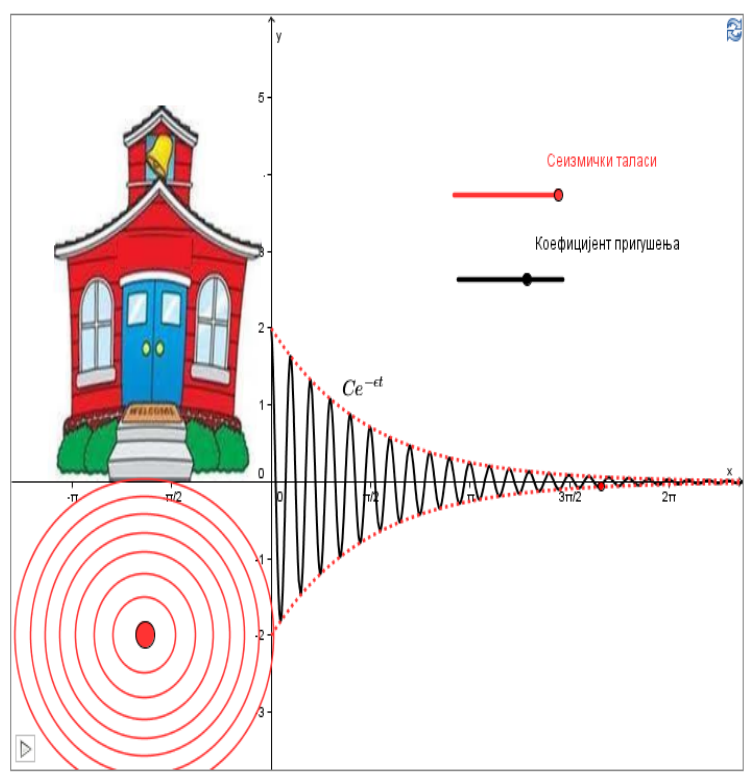

\section{Покрени анимациіу Зауствви анимацију}

Figure 5. Interactive mathematical model of damped oscillation (an earthquake problem)

In order to help teachers with different educational approaches and strategies as well as to their aims in teaching process make easier to accomplish, e-course supports different styles of lecturing as in Table 3. According to [20] Blum distinguishes between three general aims of teaching mathematics:

- "Pragmatic aims: Mathematics as an aid for describing, understanding, and mastering real world problems and situations.

- Formal aims: Mathematics as an aid for developing general skills, e.g., the ability to translate between the real world and mathematics, or attitudes such as willingness for intellectual effort.

- Cultural aims: Mathematics as a source for reflection, and mathematics as a science and a part of human history and culture." 
Table 3. Blum's general aims of teaching mathematics

in e-Differential Calculus course

\begin{tabular}{cc}
\hline $\begin{array}{c}\text { Blum's aims of } \\
\text { teaching mathematics }\end{array}$ & Usage in e-Course \\
\hline Pragmatics aims & frequent \\
\hline Formal aims & common \\
\hline Cultural aims & frequent \\
\hline
\end{tabular}

There have been published numerous studies related to: visualization in problem solving; visualization in learning; visualization in 3dimensional geometry; trigonometry, statistics, algebra; visual aspect of computer technology in dynamic learning, etc. since late 1970's according to [9], that show benefits of visualization and applications of mathematics as integral parts of the teaching process. Therefore the idea of this e-course is to show concrete examples of visualization various abstract concepts and correlations of mathematics to science and everyday life, in order to increase not only motivation, comprehension and generalization of various abstract concepts as well as achieving better results on tests.

\subsection{Visualization and GeoGebra software}

Mathematics is a subject that uses diagrams, tables, functions, spatial arrangements of signifiers such as symbols, and numerous inscriptions as essential components. Therefore it is crucial to investigate the role of visual thinking in the teaching and learning of mathematics, where the concept of visualization includes processes of constructing and transforming both visual mental imagery and all of the inscriptions of a spatial nature that may be implicated in doing mathematics according to [7].

Research on mental imagery in all of the sense modalities (sight, hearing, smell, taste, touch) and their interconnections - as in synaesthesia - was prevalent in psychology already in the $19^{\text {th }}$ century and then largely discontinued in mainstream psychology with the rise of behaviorism in the $20^{\text {th }}$ century as reported in [7].

Following the usage of Presmeg, a visual image is taken to be a mental construct depicting visual or spatial information, and a visualizer is a person who prefers to use visual methods when there is a choice. Presmeg's types of imagery used by high school learners are: "Concrete imagery ("picture in the mind"), Kinesthetic imagery (of physical movement, e.g., "walking" several vectors head to tail with fingers), Dynamic imagery (the image itself is moved or transformed) Memory images of formulae and Pattern imagery (pure relationships stripped of concrete details)." Generalization is the goal of the imagery, and visual thinking could be dispensed with after it had served its initial purpose, according to [7].

Learner's use of visualization through dynamic geometry software which facilitates visualization processes have been discussed over the years in many papers and e-course highly supports the idea as shown in Table 4 . On the other hand, results of previous mentioned studies have shown that a mathematical problem cannot be solved simply by perceiving the onscreen images, even if they are animated because it's up to student to bring some explicit mathematical knowledge to the process as well.

Table 4. Imagery in e-Diferrential Calculus course

\begin{tabular}{lc}
\hline $\begin{array}{c}\text { Presmeg's types of } \\
\text { visualization }\end{array}$ & Usage in e-Course \\
\hline Concrete imagery & less common \\
\hline Kinesthetic imagery & frequent \\
\hline Dynamic imagery & frequent \\
\hline Memory images of formulae & common \\
\hline Pattern imagery & less common \\
\hline
\end{tabular}

There are varieties of educational software which contribute educational process, especially when it comes to dynamic geometry software which have highly influenced mathematics education. The one used in this e-course is GeoGebra. It is a multilingual dynamic geometry system based on projective and Euclidian geometry in the real plane. The basic objects in GeoGebra are points, vectors, segments, polygons, straight lines, all conic sections and functions in $\mathrm{x}$ as in Figure 6. With GeoGebra dynamic constructions can be done like in any other dynamic geometry system and these constructions may be altered dynamically by dragging free objects. Furthermore, it is possible to enter coordinates of points or vectors, equations of lines, conic sections or functions and numbers or angles directly. Equations are expanded and simplified symbolically and a special grammar for arithmetical expressions in school notation has been implemented which makes this software user-friendly in terms of strengthening math skills and visualization of variety abstract concepts according to [8]. 


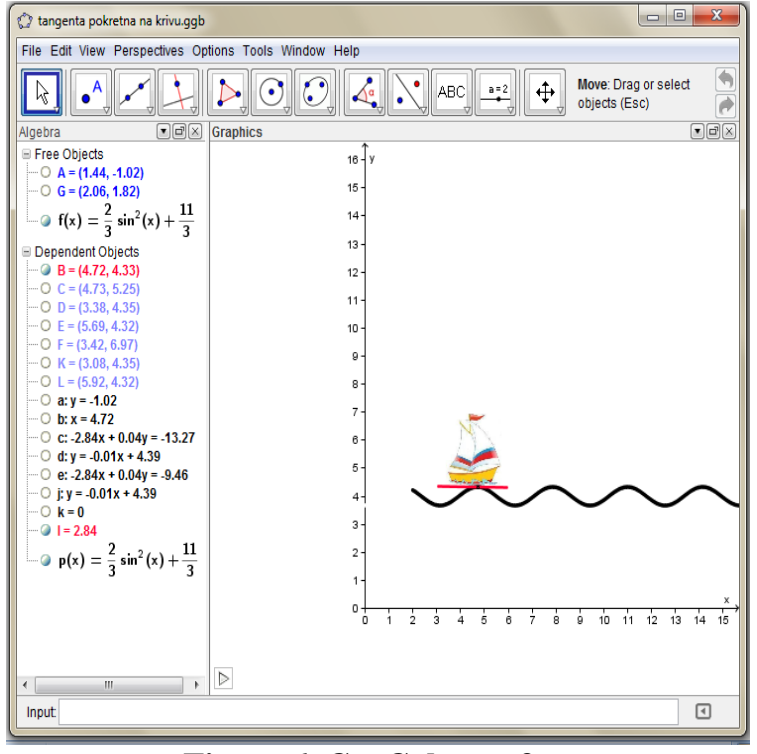

Figure 6. GeoGebra software

At the same time, user-friendly attribute is not the only one when GeoGebra is used. The name itself 'Geo' (from Geometry) and 'Gebra' (from Algebra) explains the software's purpose to correlate these mathematics areas as in Figure 6. On the other hand, it is also possible to correlate and variety of others mathematics disciplines which certainly causes more comprehensive mathematical knowledge which could be further generalized and correlated with other sciences. Still, how do visual aspects of computer technology in case of GeoGebra software change the dynamics of learning mathematics and what exactly makes imagery effective in mathematics remains a significant research topic.

\subsection{Self-regulated learning and e-Course}

Self-regulation of cognition is an important aspect of learning and positive academic performance in general, according to Paul R. Pintrichs' and Elisabeth V. De Groots' result of the study. Their research instrument - Motivated Strategies for Learning Questionnaire (MSLQ) that was used in their study, as reported in [10], measured student's motivational beliefs and self-regulated learning included topics as: Self-Efficacy, Intrinsic Value, Test Anxiety, Cognitive Strategy Use, Self-Regulation, etc.

Created e-course of Differential Calculus is designed to foster student's motivation and selfregulated learning through numerous examples as shown in Table 5. Therefore, it is essential to investigate the extent to which the aspects of created e-course influence self-regulated learning, including student's metacognitive strategies for planning, monitoring, and modifying their cognition, student's management and control of their effort on classroom academic tasks and maintaining their cognitive engagement (for example, student's capability to persist at a difficult task or block out distracters i.e. noisy classmates, etc), using conceptualization to learn, remember, and understand in order to describe how personal characteristics are related to cognitive engagement and academic performance in general according to [10].

There are several limitations to findings of Paul R. Pintrich and Elisabeth V. De Groot in [10], since motivation and cognitive components have been measured with a self-report instrument and haven't replicated with other measures, such as think aloud protocols, stimulated recall procedures, structured interviews, etc. Therefore is crucial to motivational both self-regulated attributes of e-course investigate not only with Paul R. Pintrich's and Elisabeth V. De Groot's instrument, but also and with other qualitative measures.

Table 5. Self-regulated learning components in eDifferential Calculus course

\begin{tabular}{l|c}
\hline $\begin{array}{c}\text { Paul R. Pintrich's and } \\
\text { Elisabeth V. De Groot's } \\
\text { MSLQ instrument }\end{array}$ & $\begin{array}{c}\text { Fostering self- } \\
\text { regulated learning } \\
\text { components in } \\
\text { eCourse }\end{array}$ \\
\hline Self-Efficacy & frequent \\
\hline Intrinsic Value & common \\
\hline Test Anxiety & infrequent \\
\hline Cognitive Strategy Use & frequent \\
\hline Self-Regulation & frequent \\
\hline
\end{tabular}

Although the e-material stimulates intrinsic value and motivation in students as in Table 5, it is important and to teachers to socialize student's intrinsic value since individual differences have facilitative role in learning and academic performance according to [10].

\section{Future study}

All of the challenges, potentials and influences in particular case of teaching and (or) learning supported by created e-course of the Differential Calculus and GeoGebra software in mathematics education at undergraduate university level are left to be revealed in future study.

Mixed methods research will investigate issues as: influence of personal students and teachers 
characteristics, mathematicians conceptions, actual use of e-Differential Calculus material at Universities and socio-cultural differences within and among cases. Results should be obtained from treatment and control group with pretest and posttest for each group and qualitative instruments as a self report, think-aloud protocol, stimulated recall procedures and structured interviews in order to measure not only students academic performance but also and motivation and cognitive components. Case studies of mathematics departments and mathematicians, different levels of technology integration, exemplary practices and possible extension of the study to the other countries should ensure the determination of the main indicators of good teaching practices and learning strategies in mathematics education.

Under assumption that teaching is provided by well trained teachers and properly implemented ematerial, study should provide answers to all relevant questions about the effects and contribution of created e-course in improvement of self-regulated learning, teaching process in a way that teachers can progressively construct generalizations, knowledge and students motivation.

Important aims of the study are to reveal if the major purpose of designed e-material to build a foundation for greater understanding mathematical concepts is fulfilled and which personal characteristics have the greatest impact on mathematical knowledge.

\section{Conclusion}

Teachers in Serbia generally have many opportunities to involve technology i.e. ICT in education process. National Center for the Advancement of Education and National Center for Professional Development in Education for the last several years have been promoting and conducting many seminars and workshops that are supposed to help teachers to modernize their lessons. At the same time, for the purpose of individualization and differentiation of the teaching/learning process, numerous programs are available (for example NetSupport School). These programs enable advanced management of classroom performance with variety of advantages for teaching and learning process: ability to create and use existing interactive lessons and materials, to organize activities and resources for the class, as well as evaluate the progress of students in real time, etc. On the other hand, problems as a lack of adequate teaching materials and applications (as per subject, teaching topics and content type) in Serbian language that teachers can use and display to the students in this way are not supportive in dealing with modernization of education process. Also, teachers mostly have been training to use computers, but not and how to integrate them in teaching process and the lack of examples of good ICT integrations in teaching practice are the top reasons for disuse of e-teaching both e-learning tools in classroom environment. Still, there are numerous examples of teachers who successfully integrate ICT in their lessons and furthermore, win awards on national and international level.

S.O.S. indicators of need for change of Serbian education system are numerous, as the results of PISA testing, which testify that the enormous number of students are mathematical functionally illiterate. What will happen with educational system in general if the traditional training stays basic teaching approach and how will it affects the Serbian student's academic performance in the future - time will show.

E-course of Differential Calculus is made to help pupils and teachers in order to foster their motivation, accomplishments and as example of educational e-material which can easily be incorporated in classroom environment. For consideration, it remains an open question how visualization applied in designed didactic e-material helps mathematical abstraction and generalization of the mathematical field of Differential Calculus. In order to ascertain how widespread a phenomenon of the role of dynamic visual imagery in mathematical problem solving at all levels is, it is necessary to investigate use of appropriate statistical tools and quantitative designs.

However, first of all needed is this modernized version of the mathematical area of Differential Calculus comes to life in the classroom!

\section{References}

[1] Fitzpatrick, C. (2008) 'A problem based learning (PBL) module on electronics \& the environment', in Proceedings of the 16th IEEE International Symposium for Engineering Education, ISEE'08, pp. 1-6.

[2] Andres, C. Fernando, C. Maria, C. Diego, G. and Sergio, L. (2012) 'Unifying heterogeneous e-learning modalities in a single platform: CADI, a case study' Computers \& Education, 58(1), pp. 617-630.

[3] Martín, L. Manuel, J. Juan, T. Fernando, M. (2013) 'Blended e-assessment: Migrating classical exams to the digital world', Computers \& Education (62), pp. 72-87.

[4] Hoic-Bozic, N. Mornar, V. and Boticki, I. (2009) 'A blended learning approach to course design and implementation', IEEE Transactions on Education, 52(1), pp. 19-30. 
[5] Liu, T-C. Lin, Y-C. and Bhattacharya, M. ( 2008) 'Introducing learning technologies into classroom in accordance with teacher's instructional approach', in Proceedings of 8th international conference on advanced learning technology, ICALT’08, pp. 1007-1008.

[6] Frohberg, D. Gothe, C. Schwabe, G. (2009) 'Mobile learning projects - a critical analysis of the state of the art', Journal of Computer Assisted Learning, 25(4), pp. 307331.

[7] Presmeg, N. C. (2006) 'Research on visualization in learning and teaching mathematics', Handbook of research on the psychology of mathematics education, pp. 205-235.

[8] Hohenwarter, M., \& Fuchs, K. (2004) 'Combination of dynamic geometry, algebra and calculus in the software system GeoGebra', in Proceedings of Computer Algebra Systems and Dynamic Geometry Systems in Mathematics Teaching Conference.

[9] Aspinwall, L. Shaw, K. and Presmeg, N. C. (1996) 'Uncontrollable Mental Imagery: Graphical Connections Between A Function And Its Derivative', Educational Studies in Mathematics 33(3), pp. 301-317

[10]. Pintrich, P. R. and De Groot , E. V. (1990) 'Motivational and Self-Regulated Learning Components of Classroom Academic Performance', Journal of Educational Psychology (Vol. 82, No. 1), pp. 33-40.

[11] Radojicic, M. Arsic, A. Radovic, S. Milivojevic, N. Vucicevic, M. (2011) 'Computer usage in the classroom', in Proceedings of the Symposium of Mathematics and Applications, Faculty of Mathematics, Belgrade, 3

[12] Adnađević, D. Kadelburg, Z. (2008) Matematička analiza 1, Matematički fakultet, Beograd.

[13] Božić, M. (2002), Pregled istorije i filozofije matematike, Zavod za udžbenike i nastavna sredstva, Beograd.

[14] Ivanović, Ž. Ognjanović, S. (2003) Matematika 1: zbirka zadataka i testova za 1 . razred gimnazija i tehničkih škola, Krug, Beograd.

[15] Ivanović, Ž. Ognjanović, S. (2004) Matematika 2: zbirka zadataka i testova za 2. razred gimnazija i tehničkih škola, Krug, Beograd.

[16] Ivanović, Ž. Ognjanović, S. (2005) Matematika 4: zbirka zadataka i testova za 4 . razred gimnazija i tehničkih škola, Krug, Beograd.

[17] Smirnov V. I (1974) Курс виышей математики, Nauka, Moskva.

[18] Hadžić, O. Takači, Đ. (2011) Matematika za studente prirodnih nauka, Univerzitet u Novom Sadu, Prirodnomatematički fakultet u Novom Sadu, Novi Sad.
[19] Ćorić, B. Salatić, R. (2011) Dinamika građevinskih konstrukcija, Građevinska knjiga, Beograd.

[20] Blum, W. Burghes, D. Green N. and KaiserMessmer, G. (1991) 'Teaching mathematics and its applications', Oxford University Press (Vol. 10, No 1), pp. 112-123. 
International Journal of Technology and Inclusive Education (IJTIE), Volume 3, Issue 1, June 2014 